\title{
Systematic Procedure for the Fractionation of Muscle Protein, with Particular Reference to Biochemical Evaluation of Meat Quality
}

\author{
A. AsghaR* and N. T. M. Yeates \\ Faculty of Rural Science, University of New England, N.S.W., Australia
}

Received April 10, 1974

\begin{abstract}
A systematic scheme has been developed by improving Helander's method for the separation of principal intra-cellular proteins from muscle. Helander's technique with certain modifications has been integrated with other procedures, used for the fractionation of extracellular protein (stroma) and its biophysical characterization, to make the scheme more befitting for biochemical evaluation of meat quality. Besides simplicity, reproducibility and accuracy, this scheme has many inherent advantages over the previous methods, employed for this purpose. The design of an economical extraction apparatus, which helps minimizing the experimental error in handling the samples is also presented. Any number of samples can be extracted per unit time by making a suitable assembly of the design.
\end{abstract}

It is generally believed that a change in the physico-chemical state of muscle during rigor mortis lowers the solubility of muscle protein (myosin) in some salt solutions. This phenomenon, known as "Deuticke effect" (after the name of Deuticke" who first made this observation) has been confirmed by many workers as is apparent from various reviews. ${ }^{2 \sim 4)}$

A careful assessment of the work on this aspect reveals that the state of rigor involves a type of aggregation of muscle protein in situ which is characterized by disorganization of the tissue and the formation of F-actomyosin, accompanied by loss of ATP from myofibrils. This prevents the dispersal of these proteins with certain salt solutions. ${ }^{1,5}$ ) However, the effect of rigor mortis on the solubility of protein, probably, would not be apparent, if appropriate conditions with respect to ionic strength, $\mathrm{pH}$ and temperature are employed for the extraction of protein. The difference in solubility apparently vanishes when potassium iodide or pyrophosphates are used for the extraction of muscle protein. It is postulated

* Present Address: Department of Food Technology, University of Agriculture, Lyallpur (Pakistan). This report is a part of doctorate thesis of the senior author. that KI depolymerizes F-actin to G-actin, rendering the structural protein extractable even in the absence of ATP. ${ }^{6 \sim 8}$ ) Helander's method $^{9)}$ which is being used in many laboratories, ${ }^{10 \sim 15)}$ is probably based on these findings. Apart from this, some other schemes for extraction have also been presented by $\mathrm{Khan}^{16)}$ and Hegarty et al. ${ }^{17}$ ) Most of these schemes, however, are not only limited to intra-cellular fractions (sarcoplasmic and myofibrillar) but are also time consuming. Thus, a handy and systematic scheme for the separation of major fractions of muscle protein was needed. This was accomplished by incorporating several procedures, used for the fractionation and for biophysical characterization of extra-cellular protein (stroma); this is important for biochemical evaluation of meat quality. This paper presents the details of the scheme.

\section{EXPERIMENTAL}

1. Muscle sampling. The L. dorsi muscle from Dorset Horn x Poll Merino breeding lambs (all by one sire), whose sex, growth history, and nutritional status were known, was used in the study. The left muscle at third-sixth lumber region was excised within 45 min after slaughter, wrapped in polyethylene bags and transferred to cold-storage at $2^{\circ} \mathrm{C}$, before being 
used for analysis (which was performed on pre-rigor state of muscle).

2. Sample preparation. The exposed surfaces of the muscle, together with epimysium were removed to minimize microbial contamination. Then the whole piece was cut into fine slices across the direction of fibres with a sharp stainless knife. The resulting slices were again cut longitudinally and transversely, till they were reduced to about $1 \mathrm{~mm}$ size. The whole mass was then minced and mixed thoroughly to get a homogenous body of sample. These operations were performed to reduce the probability of variation in collagenous fibres at different sites of muscle.

3. Development of the procedure. A systematic scheme was developed, after a series of trials for fractionation of muscle proteins. The final form was adopted by combining with certain modifications the procedures of Lowry et al., ${ }^{18}$ Helander, ${ }^{91}$ Jackson ${ }^{19}$ । and Eastoe and Courts. ${ }^{201}$ Its description is given in section 5. To facilitate quicker extraction of protein, an apparatus was also designed which is shown in Fig. 1 and explained below.

4. Design of the fractionation apparatus. The internal details of the design are depicted in Fig. 2. The basic idea of the extraction apparatus was adopted from Ahmad and Cook. ${ }^{21 /}$ However, some fundamental improvements were made in the original apparatus. First, the motors were arranged in series and parallel combination rather than putting all in parallel as was done in the original apparatus. With all the motors in parallel, the cell-rheostat specification become inconvenient, because to run each motor at 3 volts, $12 \times 300$ $\mathrm{mA}$ are needed. This means that 9 of the 12 volts from the battery must go across the rheostat, and further only three ohms resistance out of the ten ohms is used, with the result that the regulation of speed becomes limited. Moreover, there is a wastage of 27 watts power with all parallel system. The modified arrangement gave a better control over the regulation of the speed of the motors

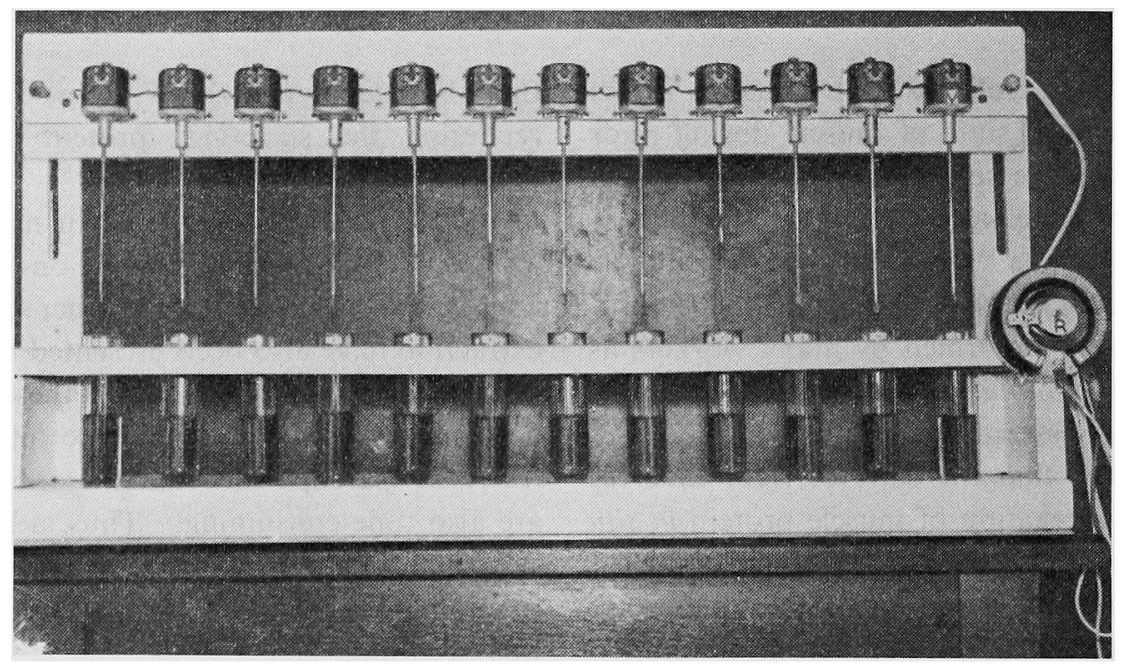

FIG. 1. Portable Apparatus for the Extraction of Muscle Proteins.

The wooden frame of the apparatus is designed partly analogous to test tubes rack to ensure easy handling of the sample. The tubes are held vertically by base and middle plates. The D.C. motors (M) with stirrers are fastened with the top plate, which can be slided down or up by loosening the two screws at the extreme ends that run across the slits in the side blocks. The speed of the motors is regulated by means of a rheostat $(R)$ to avoid frothing and hence denaturation of protein.

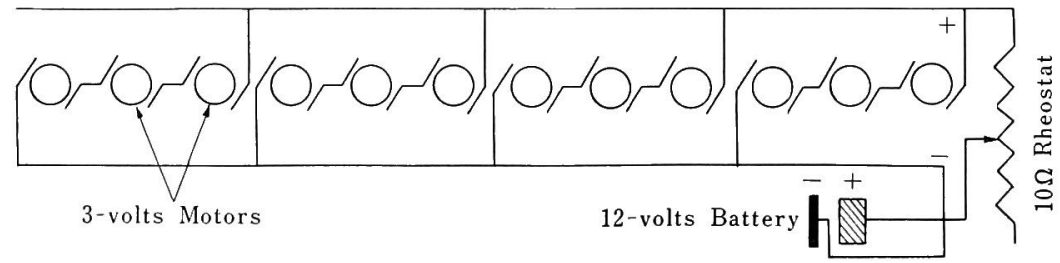

FIG. 2. The Wiring Diagram of the Series-parallel Connections between D.C. Motors. 


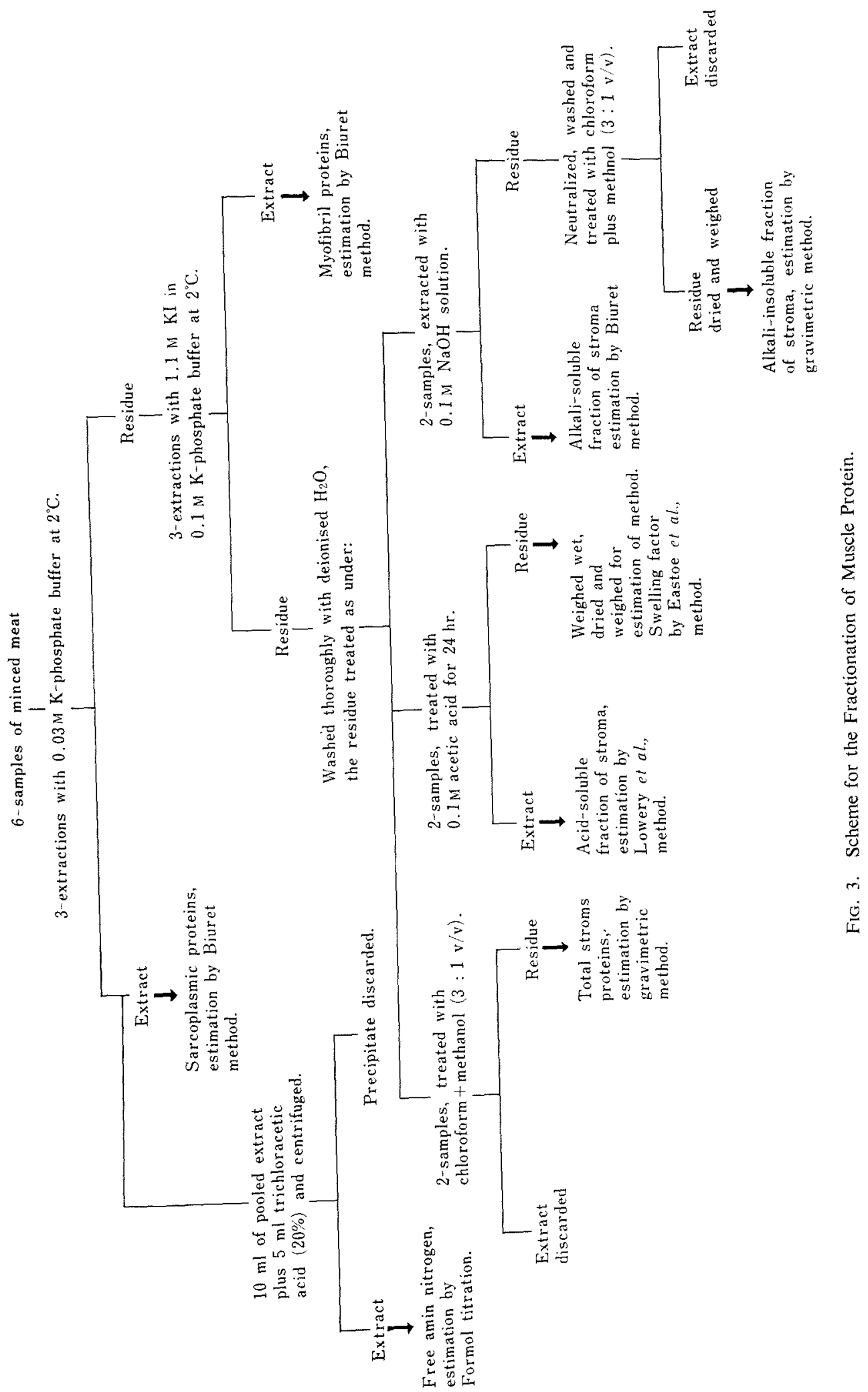


by rheostat, because 9 watts of power are consumed by the motors and only 3 watts go across the $10 \mathrm{ohm}$ resistance, from a 12 volts lead accumulator. This also provides an efficient use of the available power supply. Speed control is very important in the extraction of protein; for example high speed tends to cause froth formation hence denaturation of protein. ${ }^{22}$ Speed control was also a problem in the original design, and frequency of frothing during extraction was fairly high.

Secondly, slightly more powerful motors, 55 Mabuchi Motor, D.C. (Tokyo), were used instead of No. 45 to increase the working capacity of the apparatus. Thirdly, a brass rod stirrer ( $12 \mathrm{~mm}$ long and $3 \mathrm{~mm}$ dia.) was attached to motor's shaft through an aluminum coupling and tightened with screws. The lower end of the rod was flattened to improve the stirring capacity. This apparatus could work constantly throughout the day without over-heating or running down, which were the common features of the original design.

5. Buffer system and fractionation procedure. The extraction buffer consisted of low ionic strength buffer

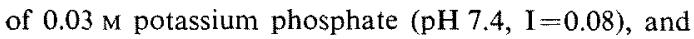
high ionic strength buffer of $1.1 \mathrm{M} \mathrm{KI}$ in $0.1 \mathrm{M}$ potassium phosphate $^{91}$ ( $\mathrm{pH} 7.4, \mathrm{I}=1.55$ ). To increase the stability of the latter buffer, $0.05 \mathrm{M}$ sodium thiosulphate was added to prevent the formation of free iodide during storage; ${ }^{23 !}$ this was a drawback in the original buffer. The base/acid ratio of the phosphate salts (di-potassium/ di-hydrogen phosphate) for desired $\mathrm{pH}$ value was calculated by the equation: $\mathrm{pH}=\mathrm{p} K^{\prime}+\log$ [base/acid]. The value of $\mathrm{p} K^{\prime}$ was derived from the equation: $\mathrm{p} K^{\prime}=$ $\mathrm{p} K+\mathrm{nAI} I^{1 / 2} / 1+1.61^{1 / 2}$. The values for $\mathrm{n}$ and $\mathrm{A}$, the constant characteristics of an acid were taken from the table ${ }^{241}$ and the ionic strength can be derived from the equation:

$$
\mathrm{I}=1 / 2 \sum[i] Z_{i}^{2},
$$

where $[i]$ and $Z_{1}$ are the concentration and the net charge of ions $i$ respectively and $\Sigma$ implies a summation overall of the ions in the solution.

Sextuplicate samples, $3 \mathrm{~g}$ each, from homogeneous minced muscle were taken directly in centrifuge tubes to extract different protein fractions stepwise with buffer systems as is illustrated in the flow-sheet diagram (Fig. 3). The reason for starting with six samples was to make the estimation of the "tail fractions" at least in duplicate. Incidently, by doing so, the statistical coverage to muscle sampling was also achieved. The sample which consisted of relatively coarse particles, tended to be less hemogenous (in ideal sense) and hence more replicates were needed.

The samples were first extracted thrice, each time for a duration of $11 / 2 \mathrm{hr}$, with pre-cooled $\left(2^{\circ} \mathrm{C}\right), 0.03 \mathrm{M}$ phosphate buffer to separate sarcoplasmic proteins. All extractions were performed at $2^{\circ} \mathrm{C}$ (if otherwise specified) to guard against denaturation of proteins. ${ }^{22}$ The residue was then similarly extracted with $1.1 \mathrm{M} \mathrm{KI}$ in $0.1 \mathrm{M}$ phosphate buffer to separate myofibril proteins. The sample and buffer ratio was kept $1: 10$ in each case. After these extractions the residues were washed twice thoroughly with deionized water and centrifuged. Duplicate samples of the residue were treated with chloroform-methnol solvent $(3: 1 \mathrm{v} / \mathrm{v})$ to remove lipids associated with connective tissue. The residue was then drained and dried. This fraction represented total stroma (extra-cellular proteins). Another pair of samples was extracted twice with $20 \mathrm{ml} 0.1 \mathrm{~N}$ sodium hydroxide, each time for $10 \mathrm{hr}$ duration at $25^{\circ} \mathrm{C}$ with occasional shaking. The extract represented the alkalisoluble fraction of stroma. The remaining residue after alkali treatment was neutralized, washed and treated with chloroform-methanol $(3: 1 \mathrm{v} / \mathrm{v})$ solvent, drained and dried at $105^{\circ} \mathrm{C}$ to a constant weight. This fraction comprised the alkali-insoluble fraction (collagen-elastin complex) of stroma. The remaining duplicate samples were treated with $0.1 \mathrm{~N}$ acetic acid for $24 \mathrm{hr}$ at $25^{\circ} \mathrm{C}$ and drained for $10 \mathrm{~min}$. The extract was used to determine acid-soluble fraction of stroma, whereas from the drained and dried weights of the residue, the hydration capacity of the extra-cellular protein (stroma) was calculated. The degree of hydration is expressed in term of a swelling factor (Sw) which is a ratio of the weight of hydrated sample (collagen) after straining free of excess water for $10 \mathrm{~min}$ to the weight of the waterfree sample:201

$$
\mathrm{Sw}=\frac{\text { wt. of the sample (drained) }}{\text { dry wt. of sample }}
$$

The magnitude of swelling factor is inversely related with the number of 'cross-linkages' in the collagen structure. ${ }^{201}$

6. Protein determination. All the extracted sanples were centrifuged for $15 \mathrm{~min}$ at $3,000 \mathrm{rpm}$, filtered and made to standard volume. One $\mathrm{ml}$ extract of each fraction (containing $3 \sim 6 \mathrm{mg}$ protein), in duplicate, was taken for estimation by biuret method, ${ }^{25}$, with a Unicam-600 spectrophotometer at $540 \mathrm{~nm}$. Samples were treated with petroleum ether to remove any lipid contamination before developing the colour. Bovine albumin (Koch-Light Laboratories) was used to prepare the standard curves for low ionic, high ionic strength and $0.1 \mathrm{M} \mathrm{NaOH}$ extracts. The $\mathrm{N}_{2}$ content of the albumin (dried in a vacuum desiccator) was estimated by micro-Kjeldahl method ${ }^{26}$ to determine the purity. The standard curves were made after applying the appropriate correction. The acid-soluble fraction of stroma, however, was determined by the method of Lowry et al., ${ }^{27)}$ because the biuret method, in spite of its certain advantages over the others, is not sensitive enough to measure the protein in a very low concentration. ${ }^{22}$ 
After the estimation of sarcoplasmic proteins, the remaining extract from the six samples was pooled, to determine the free-amino acid nitrogen. The Soreson's $\operatorname{method}^{26)}$ with some variations was followed for this purpose: To $10 \mathrm{ml}$ sarcoplasmic protein extract, in duplicate, $5 \mathrm{ml}$ trichloracetic acid was added and the samples were stirred and centrifuged. The supernatant was used for formol titration with standard $\mathrm{NaOH}$ solution. A blank consisting of $10 \mathrm{ml}$ of $0.03 \mathrm{~m}$ K-phosphate buffer plus $5.0 \mathrm{ml} 20 \%$ TCA-acid was neutralized and titrated in a similar way after addition of formaldehyde. The free-amino acid nitrogen was calculated as mmoles/100 $\mathrm{g}$ of muscle according to the expression:

Free-amino acid nitrogen (mmoles $/ 100 \mathrm{~g}$ of muscle)

$$
=-\frac{\mathrm{ml} \mathrm{NaOH} \times \text { molarity } \times 10^{3} \times 10^{2}}{\text { wt. of the sample in } \mathrm{g}}
$$

The statistical analysis of the data was also performed to compare the results, achieved by the two methods.

\section{RESULTS}

The percentages of different fractions of muscle proteins, as separated according to Helander's method ${ }^{9}$ and by improved procedure from $L$. dorsi muscle of a lamb are shown in Table I. It reveales that the standard error of the difference between means of each fraction was not significant $(P>0.05)$. This suggested that there was good agreement between the two methods. However, when judged from the extent of standard deviation and coefficient of variation among replicates for different fractions within each method, the results obtained by improved procedure were found to be more concordant than those achieved by following Helander's method. ${ }^{3}$ The data in Table II provide further support in favour of improved method. Table II shows the results of $L$. dorsi muscle from five lambs (identical in many respects) as obtained with our method. The amount of sarcoplasmic and myofibril proteins, free amino nitrogen, total stroma, alkali-soluble and alkali-insoluble stroma were fairly consistent. With the exception of acidsoluble fraction of stroma, the coefficients of variation for the other characteristics of lamb's muscle were low. They were three to six times less than those reported by Paul et al. ${ }^{28)}$ for $L$. dorsi muscle from rabbits. This difference may be attributed to our improved sample, preparation and extraction techniques.

\section{DISCUSSION}

Numerous factors, starting from sampling

Table I. Percentage of Different Proteins from a Lamb's L. dorsi Muscle, as Achieved by the Two Methods

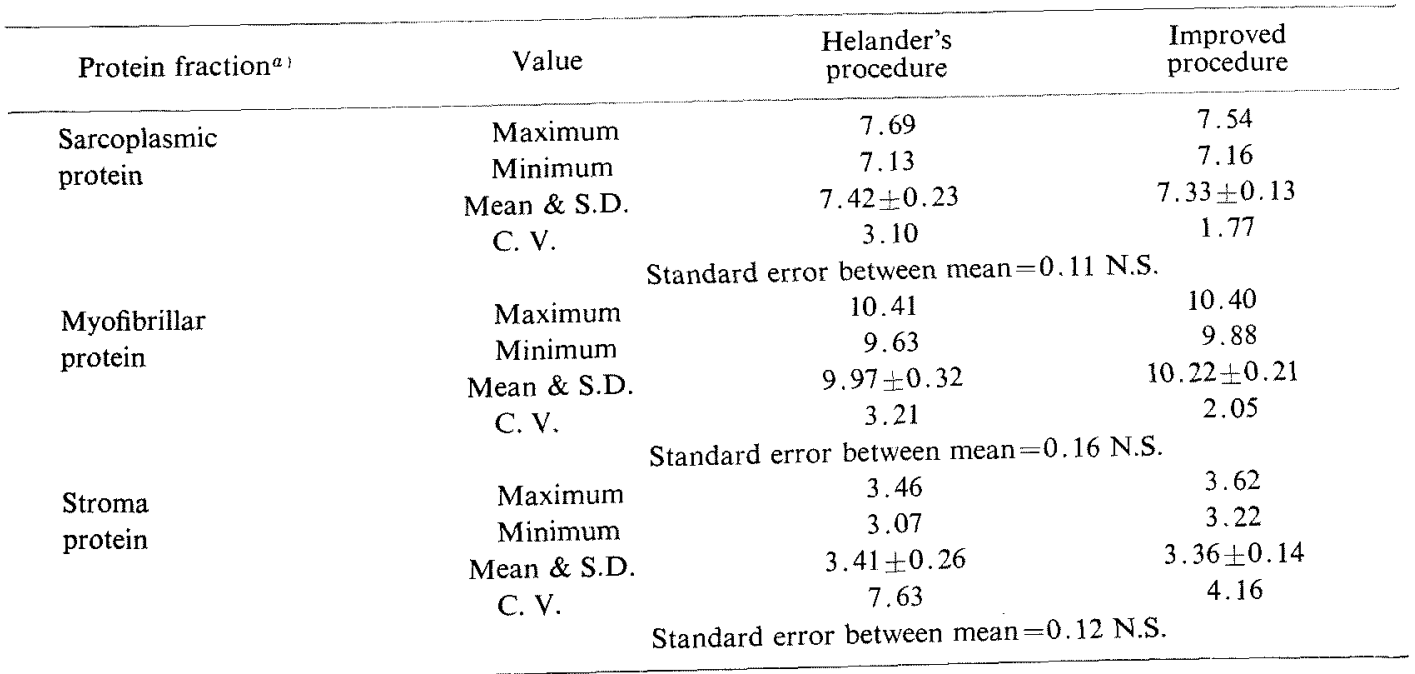

a) Number of replicates in the estimation of each fraction was six.

S.D. = standard deviation; C.V.= coefficient of variation; N.S. = non-significant at $5 \%$ probability. 
Table II. Analytical Values of Different Fractions of $L$. dorsi Muscle from Five Identical Lambs, as Achieved by the Two Methods

\begin{tabular}{|c|c|c|c|c|}
\hline & Fraction & Value & $\begin{array}{l}\text { Helander's } \\
\text { procedure }\end{array}$ & $\begin{array}{l}\text { Improved } \\
\text { procedure }\end{array}$ \\
\hline \multirow{4}{*}{\multicolumn{2}{|c|}{$\begin{array}{l}\text { 1. Free amino nitrogen } \\
\text { (mmoles/100 } \mathrm{g} \text { of muscle) }\end{array}$}} & Maximum & - & 4.91 \\
\hline & & Minimum & - & 4.04 \\
\hline & & Mean \& S.D. & - & $4.47 \pm 0.33$ \\
\hline & & C. V. & - & 7.38 \\
\hline \multirow{4}{*}{\multicolumn{2}{|c|}{$\begin{array}{l}\text { 2. Sarcoplasmic } \\
\text { proteins } \%\end{array}$}} & Maximum & 8.38 & 8.10 \\
\hline & & Minimum & 6.80 & 7.02 \\
\hline & & Mean \& S.D. & $7.55 \pm 0.68$ & $7.58 \pm 0.46$ \\
\hline & & C. V. & 9.01 & 6.07 \\
\hline \multirow{4}{*}{\multicolumn{2}{|c|}{$\begin{array}{l}\text { 3. Myofibrillar } \\
\text { proteins } \%\end{array}$}} & Maximum & 10.83 & 10.40 \\
\hline & & Minimum & 8.82 & 9.23 \\
\hline & & Mean \& S.D. & $9.95 \pm 0.86$ & $10.08 \pm 0.50$ \\
\hline & & C. V. & 8.64 & 4.07 \\
\hline \multirow{4}{*}{\multicolumn{2}{|c|}{ 4. Stroma proteins $\%$}} & Maximum & 3.79 & 4.03 \\
\hline & & Minimum & 2.82 & 3.41 \\
\hline & & Mean \& S.D. & $3.35 \pm 0.47$ & $3.78 \pm 0.24$ \\
\hline & & C. V. & 14.03 & 6.34 \\
\hline \multirow{4}{*}{\multicolumn{2}{|c|}{$\begin{array}{l}\text { a. Alkali-sol. } \\
\text { fraction of stroma \% }\end{array}$}} & Maximum & - & 3.42 \\
\hline & & Minimum & - & 2.51 \\
\hline & & Mean \& S.D. & - & $3.11 \pm 0.39$ \\
\hline & & C. V. & - & 12.54 \\
\hline \multirow{4}{*}{\multicolumn{2}{|c|}{$\begin{array}{l}\text { b. Alkali-insol. } \\
\text { fraction of } \\
\text { stroma } \%\end{array}$}} & Maximum & - & 0.62 \\
\hline & & Minimum & - & 0.46 \\
\hline & & Mean \& S.D. & - & $0.52 \pm 0.06$ \\
\hline & & C. V. & - & 11.52 \\
\hline \multirow{4}{*}{\multicolumn{2}{|c|}{$\begin{array}{l}\text { c. Acid- sol. } \\
\text { fraction of } \\
\text { stroma } \%\end{array}$}} & Maximum & - & 0.20 \\
\hline & & Minimum & - & 0.11 \\
\hline & & Mean \& S.D. & - & $0.14 \pm 0.04$ \\
\hline & & C. V. & - & 28.57 \\
\hline \multirow{4}{*}{\multicolumn{2}{|c|}{ 5. Swelling factor $(\mathrm{Sw})$}} & Maximum & - & 35.90 \\
\hline & & Minimum & $\ldots$ & 33.40 \\
\hline & & Mean \& S.D. & - & $34.60 \pm 1.07$ \\
\hline & & C. V. & - & 3.09 \\
\hline
\end{tabular}

S.D. = Standard deviation; C.V. $=$ Coefficient of variation.

to final extraction, could influence the analytical results. The unique structural features of muscle itself may be the source of variation. As the fibres of different diameters exist in a muscle, ${ }^{29 \sim 311}$ the distribution of endomysium at different sites of a muscle would naturally be uneven. The variation in the number of fibres per fasciculi in a muscle ${ }^{32)}$ also causes a disproportionate presence of perimysium per unit area. These layers, being the principal components of stroma protein, may be regarded as the source of erratic variation, especially in extra-cellular protein from different part of a muscle. Thus, special measures are needed in sampling and extraction procedures. Common mincing machine or 'Wering blender' fails to produce a homogenous sample as the collagenous fibres instead of reducing into small size, tend to entangle with the blades. Besides, there is always a tendency of frothing in Wering blender due to high speed. This consequently results in protein denaturation which could not be eliminated even by fitting the "blendo" jar with a plastic plate. ${ }^{33,34)}$ On the other hand the freezing and sectioning technique of Helander ${ }^{9}$ may not be practicable to handle a sizable quantity of muscle sample for routine analysis. Even less desirable is the 
introduction of freezing operation in the preparatory steps, which amounts to adding another source of variation in affecting protein solubilities of muscle. ${ }^{35,36)}$ However, the technique adopted in this study eliminates most of the short-comings in the preparation of a uniform sample.

Solubility of proteins in post-mortem muscle may also vary with temperature at which the muscle is held before extraction. ${ }^{34}$ However, this source of variation was eliminated as the muscle was kept at $2^{\circ} \mathrm{C}$; at this temperature denaturation of protein in muscle is not significant. $^{37)}$ Meanwhile Goll et al. ${ }^{11}$ have shown that significantly greater amount of protein were extracted by Helander's method from muscles which were excised immediately postmortem and stored at $2^{\circ} \mathrm{C}$ than from the muscle left intact with the carcass under the same conditions. This was assumed that excised muscle cooled faster and the muscle proteins were not denatured by post-mortem changes like $\mathrm{pH}$ and other factors. All these findings were taken into account while developing the present procedure.

Another, rather tire-some feature of most of the previous methods was the long duration of extraction time, needed to complete separation of different fractions. For instance, in order to have three extraction of sarcoplasmic and myofibril protein, nine hours were needed for each fraction by Helander's method. ${ }^{9 !}$ Using the extraction apparatus, illustrated in Fig. 2, the extraction time was reduced to half. Another advantage of this apparatus was that experimental errors in handling the samples were minimized as they were directly transferred in centrifuge tubes for subsequent extraction and centrifugation operations. Our apparatus was designed for handling 12 samples at a time. However, the efficiency of the apparatus can be manipulated by adding or decreasing the number of extraction units. Other types of apparatus such as Marsh-Snow homogenizer ${ }^{38)}$ do not have these advantages.

However, one fact must be born in mind that the alkali-soluble fraction is not entirely derived from collagenous fibres and the term is applied in this text with certain reservations. It is likely that the residue denoted here as extra-cellular protein may not be strictly true, in spite of Helander's ${ }^{9}$ belief that sarcoplasmic and myofibrillar proteins are completely extracted by his procedure. This residue may contain cell and nuclear membranes and some denatured proteins, which are soluble in $0.1 \mathrm{M}$ $\mathrm{NaOH}^{39)}$ and $\mathrm{HCl}$ solutions. ${ }^{40)}$ The origin of these denatured proteins is not clear. They may be sarcoplasmic ${ }^{41)}$ or myofibrillar proteins. ${ }^{42)}$ According to Smith, ${ }^{43)}$ denatured proteins consist of myosin and globulin- $X$. Hegarty et $a l .{ }^{17)}$ regarded the high ionic extract (1.1 M KI-Phosphate solution) as soluble myofibrillar proteins and $0.1 \mathrm{M} \mathrm{NaOH}$ extract as "total" myofibrillar proteins respectively. This distinction, in fact, is not based on sound theoretical reasoning, since some types of collagen are also soluble in $0.1 \mathrm{M} \mathrm{NaOH}^{19,44,45}$ ?

Considering the controversial claims by different investigators whether or not the amount of connective tissue is inversely related with the tenderness of meat, Szczesniak and Torge$\mathrm{son}^{46)}$ in their review suggested that besides amount, the structural differences in the connective tissues should also be taken into account. Since no quantitative assessment of the role of cross-linkage in determining the tenderness of meat has so far been made, the determination of swelling factor, which is an index of the extent of cross-linkages within the connective tissues becomes all the more important. For biochemical evaluation of meat quality in the present scheme, provision has been made for determining swelling factor. Using this scheme, Asghar ${ }^{47}$ has shown that swelling factor was positively correlated with organoleptic scores for components of meat tenderness such as softness to tongue and tooth pressure $(\mathrm{r}=.509,0.01<P<0.02)$, fragmentation of fibres $(r=.471,0.02<P<0.05)$ and softness of connective tissue $(\mathrm{r}=.508,0.01<P<$ 0.02 ). Multiple correlation analysis of these variates had indicated that about $26 \%$ variations in those quality factors were accounted for by the swelling factor i.e. extent of 'crosslinkages' within stroma proteins. Asghar ${ }^{47}$ ' 
has also presented the correlations of quality parameters with other physical, chemical and micro-structural characteristics of muscle in the hope of equating the 'dimensionless' components of meat quality with more exact physio-chemical characteristics.

Acknowledgements. The authors wish to thank Dr. M. A. Beg for critically going through the manuscript.

\section{REFERENCES}

1) H. J. Deuticke, Arch. ges. Physiol., 224, 1 (1930).

2) K. Bailey, Adv. Protein Chem., 1, 289 (1944).

3) E. C. Bate-Smith, Adv. Fd Res., 1, 1 (1948).

4) J. R. Whitaker, ibid., 9, 1 (1959).

5) M. Dixon and E. C. Webb, Adv. Protein Chem., 16, 197 (1961).

6) F. Guba, Nature, Lond., 165, 439 (1950).

7) O. Snellman and B. Gelotte, Expl. Cell. Res., 1, 234 (1950).

8) S. V. Perry, Biochem. J., 55, 144 (1953).

9) E. Helander, Acta Physiol. Scand., 41 (Suppl.) No. 141 (1957).

10) R. N. Sayre and E. J. Briskey, J. Fd Sci., 28, 675 (1963).

11) D. E. Goll, D. W. Henderson, and E. A. Kline, ibid., 29, 590 (1964).

12) E. D. Aberle and R. A. Merkel, ibid., 31, 151 (1966).

13) M. Yamaguchi and M. Kandatsu, Agr. Biol. Chem., 31; 1372 (1967).

14) H. Ahmad, M. Sc. thesis, Univ. of Sydney (1968).

15) E. J. Briskey and R. N. Sayre, Proc. Soc. Exp. Biol. Med., 115, 823 (1964).

16) A. W. Khan, $J . F d S c i, 27,430$ (1962).

17) G. R. Hegarty, L. J. Bratzler and A. M. Pearson, ibid., 28, 525 (1963).

18) O. H. Lowry, D. R. Gilligan and E. M. Katersky, J. Biol. Chem., 139, 795 (1941).

19) D. S. Jackson, Biochem. J., 65, 277 (1957).

20) J. E. Eastoe and A. Courts, in "Practical Analytical Methods for Connective Tissue Proteins," E. and F. N. Spon. Ltd., London, 1963, p. 111.

21) H. Ahmad and F. C. Cook, Franklin Meat Res. Lab. Univ. Sydney (1966).

22) J. F. Taylor, in "The Proteins," IA, 1, Academic
Press, N. Y., 1953.

23) A. G. Szent-Gyorgy, Archs. Biochem. Biophys, 31, 97 (1951).

24) C. Long(ed) "Biochemists' Handbook," E. and F.N. Spon Ltd., London (1961).

25) A. G. Gornall, C. J. Bardawill and M. M. David, J. Biol. Chem., 177, 751 (1949).

26) A.O.A.C. Assoc. Offic. Chemists, Washington, D.C. (1965).

27) O. H. Lowry, N. H. Rossebrough, A. L. Farr and R. J. Randall, J. Biol. Chem., 139, 265 (1951).

28) P. C. Paul, L. Buchter and A. Wierenga, J. Agri. Fd Chem., 14, No. 5, 590 (1966).

29) J. Lindhard in "Physiological Papers," eds. by R. Ege, H. C. Hegedorn, J. Lindhard and P. B. Rehberg, Heinemann, London, 1926, p. 188.

30) V.S. V. Fernand, Ph. D. thesis, Univ. of London (1949).

31) H. J. Tuma, J. H. Venable, P. R. Wuthier and R. L. Henrickson, J. Anim. Sci., 21, 33 (1962).

32) J. H. Venable, "Proc. Meat Tenderness Symp.," Campbell Soup Co., Camden, N.J., 1963, p. 7.

33) W. J. Dyer, H. V. French and J. M. Snow, J. Fisheries Res. Brd. Canada, 7, 584 (1950).

34) J. R. Dingle, D. E. Eagles and J. M. Neelin, ibid., 12, 75 (1955).

35) K. Shikama, Sci. Rept. Tohoku Univ. Ser. 4 (Biol) 29, 91 (1963).

36) T. Yasui and Y. Hashimoto, J. Fd Sci., 31, 293 (1966).

37) R. K. Scopes, Biochem. J., 91, 201 (1964).

38) B. B. Marsh and A. Snow, J. Sci. Fd Agri., 1, 190 (1950).

39) R. R. Bensley and N. L. Hoerr, Anat. Res., 60, 251 (1934).

40) R. L. Fischer in "Proc. Meat Tenderness Symp." Campbell Soup Co. Camden, N. J., 1963, p. 70.

41) J. R. Bendall and J. Wismer-Pedersen, J. $F d$ Sci., 27, 144 (1962).

42) R. N. Sayre and E. J. Briskey, ibid., 28, 675 (1963).

43) E. C. B. Smith, Proc. R. Soc. B, 124, 136 (1937).

44) C. D. Hey and G. Stainsby, Biochim. Biophys. Acta, 97, 364 (1965).

45) F. S. Stevens, ibid., 130, 196 (1966).

46) A. S. Szczesniak and K. W. Torgeson, $A d v$. Fd Res., 14, 33 (1965).

47) A. Asghar, Ph. D. thesis, Univ. of New England (1969). 